\title{
USING BIGGLOBAL DATABASE TO ANALYSE IMPACT OF WEB NEWS TO TOURIST VISITS DUE TO THE 2017 ERUPTIONOF AGUNG VOLCANO, BALI, INDONESIA
}

\author{
Putu Perdana Kusuma WIGUNA ${ }^{1}$ (D)
}

DOI: $10.21163 / \mathrm{GT} \_2021.162 .04$

\begin{abstract}
:
Bali Island, well known as The Island of The Gods, is a top tourist destination. In 2017, Agung Volcano eruption causes lots of tourist canceled their visits to Bali due to excessive news about the danger to travel to Bali. This was the first research conducted to analyses impact of volcanic disaster to tourist visits using big data in Bali, Indonesia. This research uses big global database or big data to analyses the impact of web news to tourist visits to Bali due to Agung volcano eruption. Big data is a term that describes the large volume of data, both spatial and non-spatial that inundates the world on a day-today basis. Big data in this research were processed from The Global Database of Events, Language, and Tone (GDELT) Project. GDELT project monitors the world's broadcast, print, and web news from nearly every corner of every country creating a free open platform for computing on the entire world. The purpose of this research is to analyses the impact of Agung Volcano eruption to tourist visits to Bali in 2017. Every news data sets from every country, filtered, calculated and spatially analyzed to discover the timeline and impact of Agung Volcano eruption on tourist visits to Bali in 2017. Geographic Information Systems (GIS) were used for calculation and spatial analysis. The result shows that the number of tourist visits were declining in October and November 2017 but raised again in December. November has the highest number of news related to the eruption. After the eruption in December, the number of tourist visits start to rising due to the operational of the airport. The declining caused by shutdown of Bali airport and travel warning policy from foreign country for their citizen to not to travel to Bali. Even though the number of tourists is declining in October and November, number of tourists visit on the same period in 2017 were higher than 2016.
\end{abstract}

Key-words: Agung Volcano eruption, tourist visits, big data

\section{INTRODUCTION}

In the last few years big data has getting great prominence at international arena and gaining momentum at academies, industries and other institutions. The concept of big data emerged in the scientific fraternity in the mid-1990s and become the focal point during 2008-2010. Big data including geospatial big data has so much to offer to the society in meteorology, diagnostics, disaster management, logistics, and so on (Kamali \&Augasta. 2017). As per the available data $80 \%$ of the same is geo referenced i.e., which shows the importance of geospatial big data handling. Geospatial data or spatial data is nothing but the information of a physical object, defined by values in a coordinate system. In common man's language, geospatial represents the location, size and shape of an object on earth such as a country, rivers, towns or skyscrapers (Shu, 2016).

Geospatial data collection is shifting from a data sparse to a data rich paradigm. Whereas some years back geospatial data capture was based on technically demanding, accurate, expensive and complicated devices, where the measurement process was itself sometimes an art, we are now facing a situation where geospatial data acquisition is a commodity implemented in everyday devices such as smartphones used by many people. These devices are capable of acquiring environmental geospatial information at an unprecedented level with respect to greatly improved geometric accuracy, temporal resolution and thematic granularity. They are small, easy to handle, and able to acquire data even unconsciously ( $\mathrm{Li}$, et al., 2016).

\footnotetext{
${ }^{1}$ Udayana University, Faculty of Agriculture, Indonesia, wiguna@unud.ac.id
} 
This data capture paradigm is similar to the situation in topographic data collection for digital terrain models by capturing significant topographic points with morphological characteristics on the one hand ( "qualified" points, i.e., points with semantics) - as opposed to the collection of point clouds using LiDAR sensors or stereo matching, leading to masses of "unqualified" points. The first approach requires manual selection and measurement and guarantees that the topographic reality can be interpolated from the sparse measurements. The second approach assumes that the topographic reality is captured by the dense measurements and can be reconstructed from them - thus the object formation and identification are shifted to the analysis process ( $\mathrm{Li}$, et al., 2016).

Another important feature of big data that makes it prevalent is that it provides extraordinary finegrained detailed data in terms of analysis units, spatial, and temporal resolution. For instance, smart card and mobile phone data are collected at the individual level (Richardson, et al, 2013). Such data can be observed at short intervals, for example, on a per-hour basis. Data with fine analysis units offer a significant chance for rigorous and accurate research because researchers can examine the causal relationship in a small analysis unit and avoid ecological fallacy and the other issues caused by data aggregation (Robinson, 2009). The rapid growing flood of big data, originating from the many different types of sensors, messaging systems and social networks in addition to more traditional measurement and observation systems, have already invaded many aspects of our everyday existence. Big data, including geospatial big data, has great potential to benefit many societal applications such as climate change, disease surveillance, disaster response, monitoring critical infrastructures, transportation and so on (Li, et al., 2016).

Big data generated from geo-informatics and remote sensing platforms can contribute to early warning systems for disasters. Geographical Information Systems (GIS), Global Positioning Systems (GPS) and environmental monitoring sensors with cloud services have a potential to predict disasters such as snowmelt floods and earthquakes (Fang, et al., 2015, Buribayeva, et al., 2015). Geoinformatics information along with transportation network data can benefit to understand human mobility patterns during disasters (Song et al., 2015). Whereas, social media (e.g., twitter) offers autonomously distribution of disaster awareness and can provides near to real time information of the occurrence of disasters (Cen, et al., 2011, Grolinger, et al., 2013, Choi \& Bae, 2015).

Big data has a significant role in all phases of disaster management. Big data from sensor networks, social media, and from other sources are available and shows its usefulness in disaster management already. These big data help policy makers and first responders to come with quick and concrete decision on the number of people affected, type and nature of the damage and where to allocate the resource (Rahman et al., 2017). In recent years, the literature on disaster management mostly focused on the potential that lies in using specific kinds of data for natural disaster management (Cinnamon, et al., 2016, Erdelj, \& Natalizio, 2016, Dos Santos Rocha, 2016)

One of big data platform that provides free data related to news and event around the globe is GDELT Project. GDELT or Global Data on Events, Language, and Tone is one such source where data is aggregated from various newspaper sources around the globe. GDELT database is updated with more than 30,000 events a day; hence it remains current with respect to the important events in the world on daily basis. One of the important events that aggregated at GDELT database is disaster occurrence around the globe (Leetaru, \& Schrodt. 2013, Keertipati et al., 2014).

One of major disaster event in 2017 is Agung Volcano eruption in Bali Island, Indonesia. Bali Island, despite having one of the active volcanos in Indonesia, also well-known as the best tourist island in the world. Bali has been crowned the world's favourite destination by Trip Advisor (Paris, 2017, Nurhayati, 2017, Christo, 2017). The threat of Agung Volcano eruption has provided a direct example of how natural disasters shock Bali tourism. Thousands of tourists were affected by the eruption due to airport closing, flight cancelation and travel warning (Rahmawati et al, 2019). Overall, the eruption had an impact on many tourists cancel their visit to Bali. This research on using big global database to analyze disasters was the first research and it has never been conducted in Bali. Using the GDELT database, this research aims to filters news on the Agung Volcano eruption and try to understand the effect of news of the eruption to the number of tourist visits to Bali, Indonesia. 


\section{LITERATURE REVIEW}

\subsection{Agung Volcano}

Agung volcano is Bali's highest and most sacred mountain, towers over the eastern end of the island, in Karangasem Regency. The Agung volcano, whose name means "Paramount," rises above the SE caldera rim of neighboring Batur volcano, and the northern and southern flanks extend to the coast. The summit area extends $1.5 \mathrm{~km} \mathrm{E-W}$, with the high point on the $\mathrm{W}$ and a steep-walled 800$\mathrm{m}$-wide crater on the E. The Pawon cone was located low on the SE flank. Only a few eruptions dating back to the early 19th century have been recorded in historical time. The 1963-64 eruption, one of the largest in the 20th century, produced voluminous ashfall along with devastating pyroclastic flows and lahars that caused extensive damage and many fatalities (Global Volcanism Program, 2018).

Increases in seismic activity were first noted at Agung Volcano during mid-August 2017. Exponential increases in the rate of events during the middle of September led PVMBG to incrementally raise the Alert Level from I to IV (lowest to highest) between 14 and 22 September. Steam-and-gas emissions were intermittently observed 50-500 $\mathrm{m}$ above the summit crater from the end of September through October, with occasional bursts as high as $1,500 \mathrm{~m}$. Seismicity dropped off almost as quickly as it rose, beginning on 20 October, and then continued a more gradual decrease through the end of the month and into November. The number and intensity of hot spots observed within the summit crater increased during September, then levelled off during October. Ash emissions first appeared on $21^{\text {st }}$ of November, rising to $700 \mathrm{~m}$ above the summit. Ash density and heights of plumes increased several times during the rest of November to about 3,000 $\mathrm{m}$. Ashfall as deep as 5 $\mathrm{mm}$ affected neighboring communities, and was reported several hundred kilometers from the summit; the international airport about $60 \mathrm{~km} \mathrm{SW}$ was forced to close for a few days at the end of the month. Thermal data indicated effusion of lava into the summit crater at the end of November. After 30 November, emissions continued, primarily comprised of steam and gas, with intermittent plumes of dense ash, rising up to $2.5 \mathrm{~km}$ above the summit throughout December (Global Volcanism Program, 2018).

\subsection{Bali Tourism}

Bali tourism has become a world-famous tourist destination all over the world. It is proven that the visit of foreign tourists and domestic tourists to Bali from year to year is increasing (Antara \& Sumarniasih, 2017, Anom, et al., 2020). However, it is not only tourist visits for vacation that cause the development factor of tourist visits to Bali to increase, but the frequent holding of international events is also one of the development factors for the increase in visits.

The attraction of Bali tourism is not only found in the arts and culture of the Balinese people, but also in the natural beauty such as white sand beaches, sunset views and mountain views (Arismayanti, 2017). Bali's natural tourism with the beautiful natural scenery such as in Kuta Beach, Jimbaran, Uluwatu, Kintamani, Lake Batur and towering Mount Batur, Gitgit Waterfall Tourism Object, Natural Hot Springs, is the main attraction for most tourists, for a vacation to the island of Bali.

Bali also has uniqueness in culture that become a very interesting tourist attraction (Wesnawa, 2017, Pratiwi, et al., 2019). Local traditional village or ancient Bali village such as Tenganan, Trunyan, Penglipuran and others has uniqueness that are different from another traditional village in the world.

For nature lovers, adventure tourism in Bali is one of the best. Climbing to the top of the highest volcano in Bali, Agung Volcano will provide many valuable experiences. This activity is indeed favored by foreign and domestic tourists. Ascent to the highest mountain in Bali with a start point at the cultural location of Pasar Agung Temple or from Besakih Temple and then climb to peak to enjoy sunrise. Tours to Agung Volcano, the active volcano in Bali, which located in Rendang District, Karangasem Regency, are certainly a special moment for tourists. Agung volcano is also believed to be a sacred mountain in Bali (Mudana, et al., 2018). 
Beside adventure tourism, the nearby popular tourist location are Besakih Mother Temple, Pasar Agung Temple, Sidemen village and recreational rafting on the Telaga Waja river. Tourists who take part in group tours can also take the time to stop by to some of these attractions and feel the unique nature beauty and village life.

\subsection{Global Data on Events, Language, and Tone (GDELT) Database}

GDELT Data is the largest, most comprehensive, and highest resolution open database ever created. Just 2015 data alone has recorded nearly three-quarters of a trillion snapshots and over 1.5 billion location references, making it one of the largest spatial-temporal data sets in existence and encouraging studies using freely available big data. GDELT's Global Knowledge Graph (GKG) connects the people, organizations, locations, themes, numbers, images and emotions into one holistic network across the planet. Each GKG record is a pairing of a set of names, events, counts, actors, locations, themes, and tones (GDELT, 2019, Hopp, et al., 2019).

The GDELT project is an ongoing effort to monitor print, broadcast and web news in more than 100 languages from around the world and to keep them updated. GDELT is moving beyond the focus of Western media towards a much more global perspective on what is happening in the world. The GDELT project created by Kalev Leetaru of Georgetown University in collaboration with Google, BBC Monitoring, National Academies Keck Futures Program, LexisNexis Group, JSTOR, DTIC, and the Internet Archive (GDELT Project, 2019).

The GDELT Events Database records more than 300 categories of activity worldwide, from riots and protests to peace calls and diplomatic exchanges. The existing database consists of more than 2.5 $\mathrm{TB}$ of available information per year with more than a quarter of a billion records. The platform covers data from 1979 to the present, and is updated every 15 minutes, meaning that there is a continuous stream of records being entered into the database. (GDELT Project, 2019).

\subsection{Previous Research}

So far, only a few scholars have conducted research in utilizing GDELT to make predictions about disaster. Previous research showed that GDELT database has used to analyses natural disasters, as demonstrated for Nepal earthquake (Yu, et al., 2016) and hurricanes (Owuor, et al., 2020). Yu, et al., (2016) was using GDELT to show the dynamics of people's attention to Nepal earthquake. In addition, also using other datasets to analyses funds and donation related to the earthquake reconstructions process. Available dataset and surveys from citizens in affected areas along with the reconstruction dataset help capture and explain the efforts that the international and local organizations and governments have put on the post-earthquake relief, and its effectiveness. Owuor et al., (2020) was comparing GDELT data and geo-tagged tweets related to hurricane in Dorian in South-Eastern USA and then statistically analyzed the distance between daily GDELT events, tweets, and the hurricane center in different days. It assesses the potential role of geographic coverage in the hurricane prediction map on the level of event related news and tweeting activities.

Tourism is shaped by a wide range of factors and forces, including exogenous ones that have no direct link with the tourism sector. Natural disasters and unexpected events are prime examples of such determining factors, as they have profound effects on tourism flows considerably. A volcanic disaster can affect tourism for obvious reasons because there is a very close link between tourism and natural disasters. In the event of a natural disaster tourism is significantly disrupted and in many cases the industry is destroyed, requiring redevelopment and adjustment (Gaudru, 2014, Rosello et al., 2020). GDELT database has never been used for volcanic disaster analysis, especially related to volcanic eruption and the effect on tourism in Bali. The news about volcanic eruptions may affects tourist to cancel their arrivals to Bali. It is interesting to analyzed whether the news were able to influence tourists to cancel their visit to Bali which lead to reducing number of tourist visits. 


\section{STUDY AREA}

Area of study is Bali Province, Republic of Indonesia; with the capital city is Denpasar City. Bali Province is an island which famously known as The Island of the Gods (Tallon, 2013, Parimartha et al., 2016). Bali is a small island around $5,636.66 \mathrm{Km}^{2}$ which divide into 8 Regency and one Municipality. Total population from 2017 about 3,890,757 inhabitants. Its major potential economic development are emphasized on tourism and agriculture (Center Bureau of Statistics of Bali Province, 2017). Fig 1. shows the map of Bali Province.

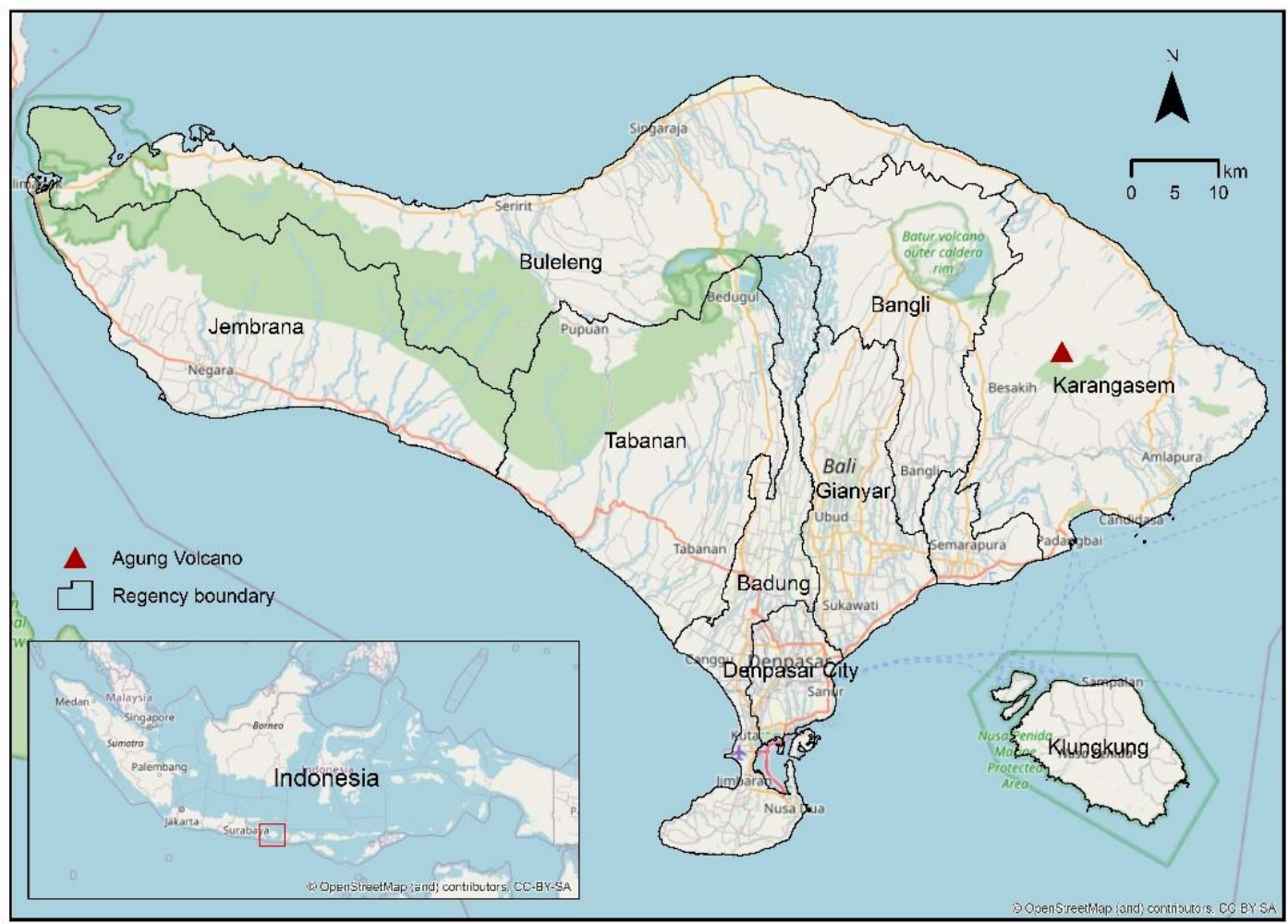

Fig. 1. Map of Bali Island on OSM Basemap.

\section{DATA AND METHODS}

The research materials were GDELT Project's GDELT 1.0 Global Knowledge Graph (GKG) data of 2017 (The GDELT Project, 2017) and tourist visits data of 2016 and 2017 from Centre Bureau of Statistics (BPS) of Bali Province. The research tool is computer with office tool and GIS software.

GKG dataset offers various fields to describe the characteristics of natural and man-made disasters, such as the type of a disaster, the number of news articles reporting the disaster, the number of victims, and the location where the disaster occurred (Kwak and An, 2014). GDELT Project's daily GDELT 1.0 Global Knowledge Graph (GKG) data of 2017 which available to download freely then sorted out to find the related news about Agung Volcano eruption from all around the world. This data then visualized and analyzed to find the relation between the Agung Volcano eruption news and tourist visits to Bali province. Before data visualization process, news extraction carried out to prevent hoax news by ascertaining the source of the news and its author as well as tracing the sources cited in the news. Hoax news related to disasters will be different from other news in terms of themes and content. 
The extraction started by identifying all GKG records falling under the "AGUNG" and "ERUPTION" theme. Based on this theme, the Event mentions table was searched for AGUNG ERUPTION related articles during the study period. GDELT entries in the Events table were filtered to WORLDCITY and WORLDSTATE. Each location in the GKG comes with a latitude/longitude pair which represents the centroid of the location (Owuor, et al., 2020).

Data analysis including creation of spatial analysis and non-spatial analysis including Attribute Query, Spatial Query and Generation of new data sets from the original database. Attribute query including creation of new non-spatial attribute from the GKG data, spatial query including creation of point data of the location distribution of news source related to Agung volcano eruption and generation of new data sets from the spatial query and non-spatial query.

Data on tourist visits before and during the eruption of Agung Volcano, in 2016 and 2017, was obtained through the news portal from the Central Bureau of Statistics (BPS) of the Province of Bali and information from the Tourism Office of the Province of Bali. Monthly tourist visit data will be matched with the amount of news about the eruption of Agung Volcano to find out whether news about the eruption of Agung Volcano affects the number of tourist visits to Bali.

\section{RESULTS AND DISCUSSIONS}

There were 9492 news related to Agung Volcano eruption from 231 countries in 2017. As much as 1014 news (10.6\%) were came from top 10 countries of Indonesia, Japan, United Kingdom, Australia, China, Italy, India, France, Russia and Canada. Fig. 2 shows the spatial distribution of news related to Agung Volcano Eruption.

Using heatmap analysis, the most news were coming from Indonesia, with other were distributed in South East Asia, South Asia, Europe, North America and Australia. Africa and South America were less contributed to the news to Agung Volcano eruption. Fig. 3 shows the heap map of news distribution related to Agung Volcano Eruption. The news related to Agung Volcano eruption started in $14^{\text {th }}$ of September 2017. The news mainly about the raised alert level for the Agung Volcano in Bali following an increase in seismic activities and volcanic earthquakes.

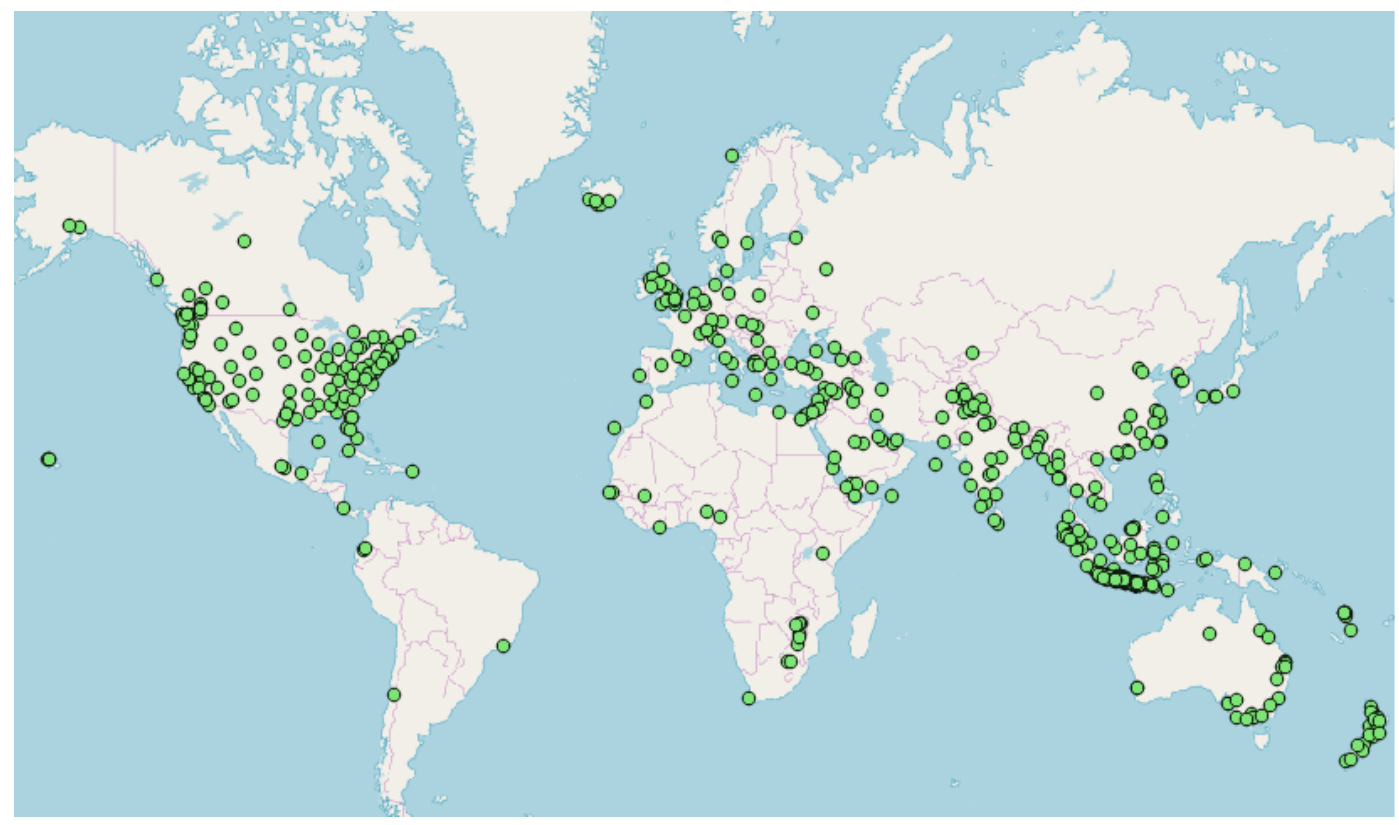

Fig. 2. Spatial Distribution of News Related to Agung Volcano Eruption. 
The National Disaster Mitigation Agency said the alert has been raised and recommends villagers to stay further than 6 kilometers (3.8 miles) from the mountain's crater (Chosunilbo \& Chosun, 2017, Phys.org, 2017, The Daily Mail, 2017, The Hindu, 2017, The Washington Times, 2017, Marboen, 2017). The highest number of news posted in September started from $22^{\text {nd }}$ until $30^{\text {th }}$ with the highest number of news was on the $26^{\text {th }}$ with total of 320 news. The news mainly focused on Indonesian Government that raised the alert level for a volcano to the highest level with more than 11,000 villagers have left their homes around the mountain and more evacuations were expected (Astro Awani, 2017, Belfast Telegraph, 2017, Calgary Herald, 2017, Whiteside, 2017).

In October, from the $1^{\text {st }}$ until $6^{\text {th }}$ the news the news related to Agung Volcano generally focused on the evacuees who live outside the immediate danger zone to return home. The status of Agung Volcano was lowered on the $29^{\text {th }}$ of October. A statement by the Indonesian National Agency for Disaster Management said evacuated residents within the designated hazard should stay put, but villagers outside the hazard zone could safely go home but should not venture close to the crater, which was still emitting smoke (Arkansas Online, 2017, Fox News, 2017, Humanitarian News, 2017, Mail Online, 2017, Relief Web, 2017, The Denver Post, 2017).

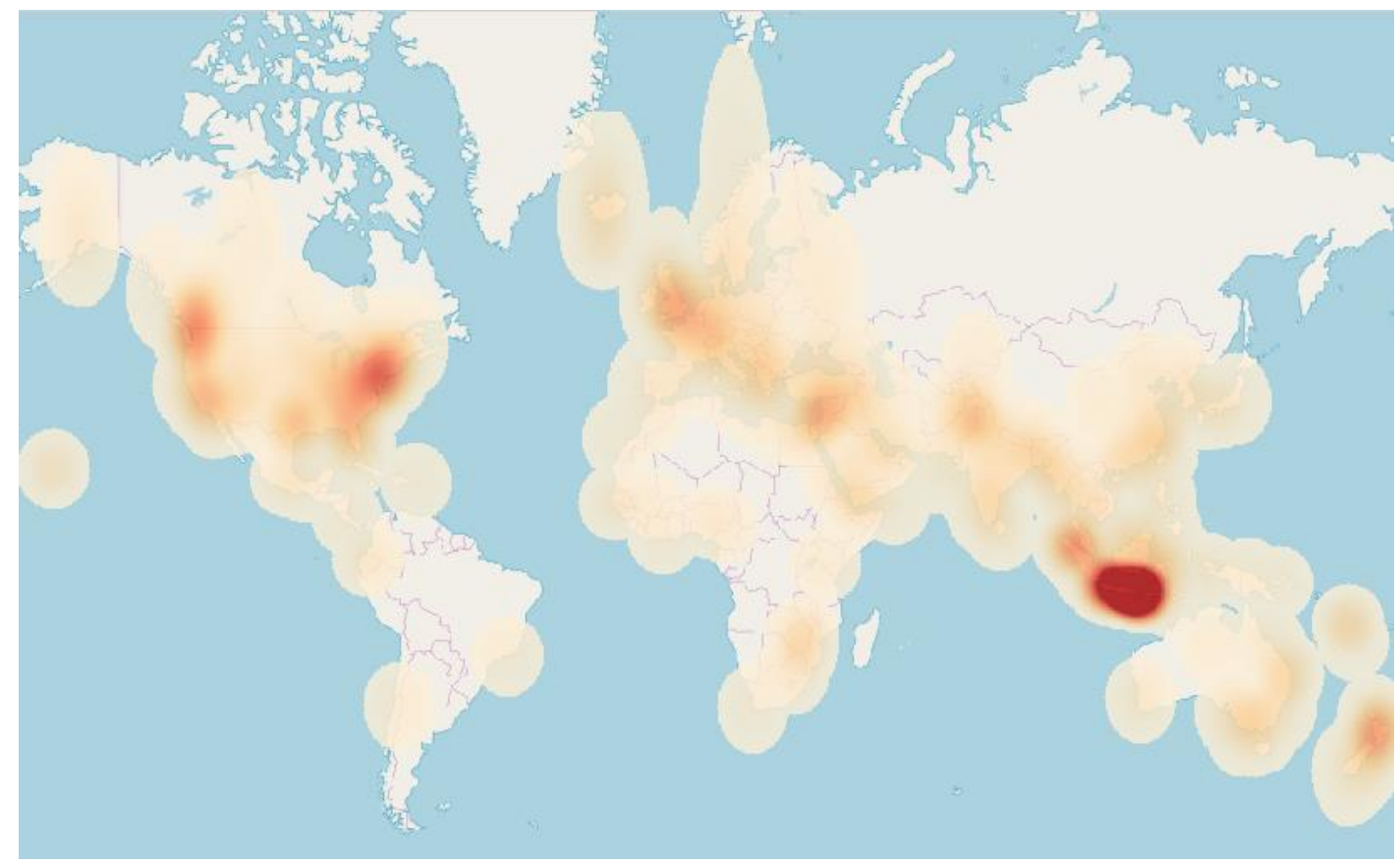

Fig. 3. The Heap Map of News Related to Agung Volcano Eruption.

In November, the news related to Agung Volcano eruption started from the $21^{\text {st }}$ until $30^{\text {th }}$ and peaked at $27^{\text {th }}$ with 1646 news. The first three weeks of November there were no significant activity of Agung Volcano. At $21^{\text {st }}$ of November the first ash emission was appeared, rising to $700 \mathrm{~m}$ above the summit (Global Volcanism Program, 2018). The news from $21^{\text {st }}$ until $26^{\text {th }}$ of November mainly about the eruption of Agung Volcano which releasing ash and smokes from crater producing imminent heavy ash rain. Volcanologists say the eruption was caused by magma heating water, or phreatic eruption, rather than a generally more dangerous eruption of magma itself. The Energy and Mineral Resources Ministry's Volcanology and Geological Hazard Mitigation Center (PVMBG) reported that Agung Volcano has erupted, releasing volcanic ashes and smoke from the crater. The eruption occurred at 5.05 p.m. local time, with grey smoke rising about 700 meters from the crater. From $27^{\text {th }}$ until $30^{\text {th }}$ of November, the world pays attention on the Agung Volcano eruption and the shuts down Bali and Lombok airport. The volcano has shifted from steam-based eruptions to 
magmatic eruptions. Indonesian authorities raised the alert for a rumbling volcano to the highest level on Monday and closed the international airport including international airport on the neighboring island of Lombok. At $30^{\text {th }}$ of November, the airport re-opens even though Agung Volcano still erupted. The exclusion zone around the crater was widened to 10 kilometers (6 miles). Previously it ranged between 6 kilometers and 7.5 kilometers (ABC 57 News, 2017, France 24, 2017, Oman Daily Observer, 2017, The Indian Express, 2017, The Star Online, 2017, World Buletin, 2017).

The news of Agung Volcano eruptions in December began with 318 news on the $1^{\text {st }}$ day and declining until reached 45 news on the $8^{\text {th }}$. The news in December were mainly about the Agung volcano was calm, emitting only a thin column of sulfuric steam. The volcano's alert remains at the highest level but Bali is safe except for the 10-kilometre exclusion zone. Bali international airport was operating normally. From the second week of December the news were mainly about the European Union support to Agung Volcano eruptions victim and the effect of the disaster to tourism in Bali. Indonesia Coordinating Minister for Maritime Affairs Luhut Pandjaitan said that Bali was safe for those spending yearend holiday as volcanic impacts from Agung Volcano will not affect tourism spots (Asia Pasific Daily, 2017, European Council, 2017, Fresh News Asia, 2017).

November has the highest number of news related to agung Volcano eruption. As much as 5852 news $(61.65 \%)$ from around the world were posted in November, followed by September with 2057 news $(21.67 \%)$ and December with total of 1125 news $(11.85 \%)$. The lowest number of news were in October with total of 458 news related to Agung Volcano eruption Table 1 shows the number of news related to Agung Volcano eruption. Fig. 4 shows daily number of news related to Agung Volcano eruptions.

Number of News Related to Agung Volcano Eruption.

Table 1.

\begin{tabular}{crr}
\hline Month & Number of News & \% of News \\
\hline$\ldots$ & 0 & 0 \\
Sep & 2057 & 21.67 \\
Oct & 458 & 4.82 \\
Nov & 5852 & 61.65 \\
Dec & 1125 & 11.85 \\
\hline TOTAL & $\mathbf{9 4 9 2}$ & $\mathbf{1 0 0}$ \\
\hline
\end{tabular}

Agung Volcano eruption last for 4 months from September until December 2017. Many news agencies have reported the development of the eruptions and analyses the impact to tourist visits to Bali. Travel warning, airport closed and flights were several factors that might affect the tourist visits to Bali especially on the holiday seasons in December. Based on data of tourist visits to Bali from Center Bureau of Statistics of Bali Province and Tourism Office of Bali Province, at the peak of Agung Volcano eruptions in November, total tourists visit to Bali was 741,649 compared to 655,962 tourists in November 2016. In December, total tourist visits were 939,048 compared to 882,026 in December 2016. This number was smaller compared to September 2017 with total tourist visits reached 832,026. Total 8,643,680 tourist was visiting Bali in 2016 and total 8,735,633 was visiting Bali in 2017. This indicates that the number of tourists that visiting Bali was increasing. Table 2 shows the number of tourists visit to Bali in 2016 and 2017 compared to the number of news related to Agung Volcano eruption. At the start of the news about Agung Volcano at $14^{\text {th }}$ of September, there were no significant decline in tourist visits. This is because tourists were already in Bali. During the closing of the Airport lot of tourists were unable to come back to their country of origin. At the peak of Agung Volcano eruption in November 2017, the number of tourists was declining as the news of Agung Volcano eruptions were increasing. 

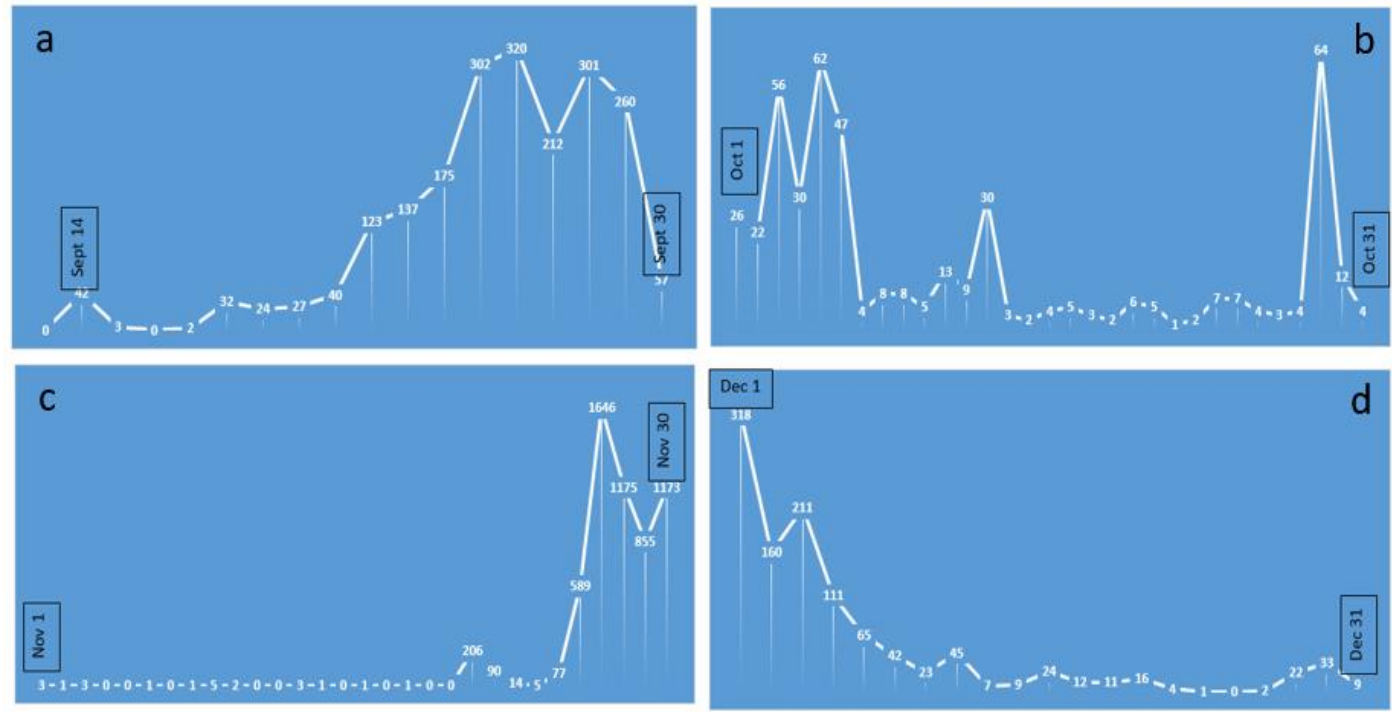

Fig. 4. Number of Daily News of Agung Volcano Eruptions; (a) September; (b) October;

(c) November; (d) December.

After the eruption, the number of tourist visits start to rise in December due to the operational of the airport. The declining was caused by shutdown of Bali Airport and travel warning policy from foreign country to their citizen to not travel to Bali. Even though the number of tourists were declining in October and November 2017, total number of tourist visits in September until December 2017 were higher than September until December 2016. Fig. 5 shows the monthly number of tourists visit to Bali in 2016 and 2017 compared to the number of news related to Agung Volcano eruption.

The number of tourists visit to Bali in 2016 and 2017

Table 2. compared to the number of news related to Agung volcano eruption.

\begin{tabular}{lccr}
\hline \multicolumn{1}{c}{ Month } & $\mathbf{2 0 1 6}$ & $\mathbf{2 0 1 7}$ & News \\
\hline Jan & 597558 & 658308 & 0 \\
Feb & 513852 & 520462 & 0 \\
Mar & 576438 & 618834 & 0 \\
Apr & 534395 & 705710 & 0 \\
May & 647790 & 646467 & 0 \\
Jun & 1035563 & 659718 & 0 \\
Jul & 1084950 & 890368 & 0 \\
Aug & 704662 & 790323 & 0 \\
Sep & 725240 & 832026 & 2057 \\
Oct & 685244 & 732720 & 458 \\
Nov & 655962 & 741649 & 5852 \\
Dec & 882026 & 939048 & 1125 \\
\hline TOTAL & $\mathbf{8 6 4 3 6 8 0}$ & $\mathbf{8 7 3 5 6 3 3}$ & $\mathbf{9 4 9 2}$ \\
\hline
\end{tabular}




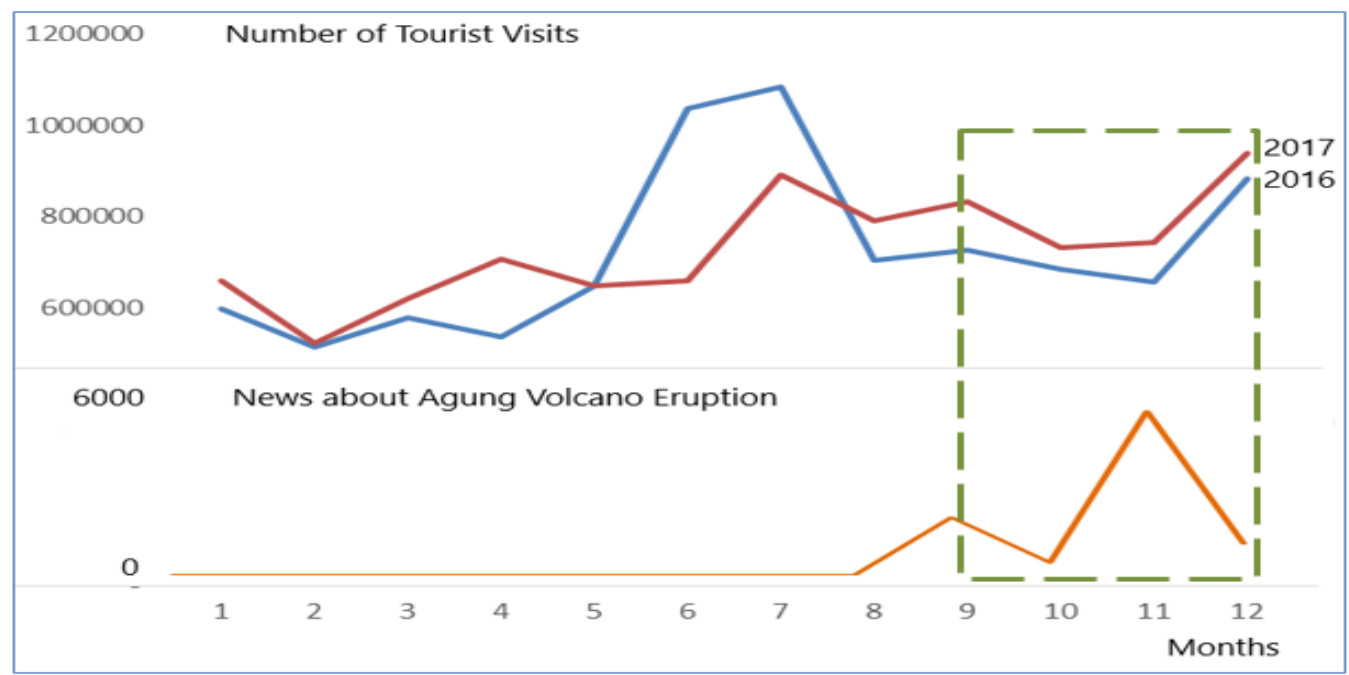

Fig. 5. The monthly number of tourists visit to Bali in 2016 and 2017 , compared to the number of news related to Agung volcano eruption.

\section{CONCLUSIONS}

The news about Agung Volcano eruption started at 14th of September 2017 until the end of December which indicates that the eruption process was taking a long time. The news in September mainly about Indonesian Government that raised the alert level for a volcano to the highest level with more evacuations are expected. In October about the status of Agung Volcano was lowered and the evacuees who live outside the immediate danger zone to return home. In November the news mainly about Agung Volcano eruptions which triggered the shutdown of Bali and Lombok airport. In December the news was mainly about the Agung volcano was calm, even though volcano's alert remains at the highest level but Bali is safe except for the 10-kilometre exclusion zone. Bali's international airport was operating normally.

Total tourists visit to Bali at the peak of Agung Volcano eruptions in November was 741,649 compared to 655,962 tourists in November 2016. In December, total tourist visits was 939,048 compared to 882,026 in December 2016. The number of tourists is declining in October and November but rising again in December. November has the highest number of news related to the eruption. After the eruption in December, the number of tourist visits start to rising due to the operational of the airport. The declining caused by shutdown of Bali airport and travel warning policy from foreign country to their citizen to not to travel to Bali. Even though the number of tourists is declining in October and November, number of tourists' visit in September until December 2016 were higher than September until December 2016.

\section{R E F E R E N C E S}

ABC 57 News. 2017. Bali Volcano Shuts Downs Flights, Sends Residents Scurrying To Safety. WBND. Last access on September 2020. http://www.abc57.com/news/bali-volcano-shuts-downs-flights-sends-residentsscurrying-to-safety.

Anom, I.P., Mahagangga, I.G.O., Suryawan, I.B., Koesbardiati, T. \& Wulandari, I.G.A. 2020. Case study of Balinese tourism: Myth as cultural capital. Utopía y Praxis Latinoamericana, 25(6), 122-133. doi: 10.5281/zenodo. 3987586

Antara, M \& Sumarniasih, M.S. 2017. Role of Tourism in Economy of Bali and Indonesia. Journal of Tourism and Hospitality Management, 5(2), 34-44. doi: 10.15640/jthm.v5n2a4. 
Astro Awani. 2017. Volcano On Indonesia's Bali Island At Highest Alert Level, Thousands Evacuated. Astro Awani Network Sdn. Bhd. Last access on November 2020. https://calgaryherald.com/pmn/news-pmn/nearly10000-leave-homes-around-active-bali-volcano/wcm/467a9fcf-fb59-48a5-8ab0-cd9546fb3d88

Arkansas Online. 2017. Some Who Fled Volcano Can Go Home. Arkansas Democrat-Gazette, Inc. Last access on November 2020. https://www.arkansasonline.com/news/2017/oct/01/some-who-fled-volcano-can-gohome-20171/

Arismayanti, N.K. 2017. Branding Strategy of Tourism in Bali Based on Cultures and Heritage. $8^{\text {th }}$ International Science, Social Science, Engineering and Energy Conference, 1-14.

Asia Pasific Daily. 2017. Indonesia Declares Bali Returns to Normal, Airport Closure Unlikely. Asia Pasific Daily. Last access on September 2020. https://www.apdnews.com/e-world/807317.html.

Buribayeva, G., T. Miyachi, A. Y. and Y. Mikami. 2015. An Autonomous Emergency Warning System Based on Cloud Servers and SNS. Procedia Computer Science 60, 722-729.

Belfast Telegraph. 2017. 11,000 Evacuated As Indonesia Raises Volcano Alert On Bali. Belfast Telegraph Ireland. Last access on November 2020. https://www.belfasttelegraph.co.uk/news/world-news/11000evacuated-as-indonesia-raises-volcano-alert-on-bali-36158999.html

Calgary Herald. 2017. Nearly 10,000 Leave Homes around Active Bali Volcano. Associated Press. Last access on November 2020. https://calgaryherald.com/pmn/news-pmn/nearly-10000-leave-homes-around-activebali-volcano/wcm/467a9fcf-fb59-48a5-8ab0-cd9546fb3d88

Cinnamon, J., S.K. Jones, and Adger, W.N. 2016. Evidence and Future Potential of Mobile Phone Data for Disease Disaster Management. Geoforum 2016, 75, 253-264.

Cen, J., T.Yu, Z. Li, S. Jin and S. Liu 2011. Developing A Disaster Surveillance System Based On Wireless Sensor Network And Cloud Platform. IET International Conference on Communication Technology and Application (ICCTA).

Center Bureau of Statistics (BPS) of Bali Province. 2017. Bali in Figure. Denpasar: Center Bureau of Statistics (BPS) of Bali Province.

Channel News Asia. 2017. Indonesia's Mount Agung Erupts For a Second Time. Mediacorp. Last access on November 2020. https://www.channelnewsasia.com/news/asia/indonesia-s-mount-agung-erupts-for-asecond-time-bali-9440086

Choi, S \& Bae, B. 2015. The Real-Time Monitoring System of Social Big Data for Disaster Management. Computer Science and its Applications, pp. 809-815, Springer Berlin Heidelberg.

Chosunilbo \& Chosun. 2017. Indonesia Raises Alert Level for Bali Volcano. Digital Chosun Inc. Last access on November 2020. http://english.chosun.com/site/data/html_dir/2017/09/15/2017091500541.html

Christo, J.P. 2017. Bali named TripAdvisor's Best Destination in the World. Tempo Inti Media TBK. Last access on November 2020. https://en.tempo.co/read/news/2018/03/07/199916400/Bali-named-TripAdvisors-BestDestination-in-the-World

Dos Santos Rocha, R., A. Widera, R.P. van den Berg, J.P. de Albuquerque, B., Helingrath. 2016. Improving the Involvement of Digital Volunteers in Disaster Management. Proceedings of the International Conference on Information Technology in Disaster Risk Reduction, Sofia, Bulgaria, 16-18 November 2016; Murayama, Y., Velev, D., Zlateva, P., Gonzalez, J.J., Eds.; Springer: Cham, Switzerland, 2016; 214-224.

Erdelj, M. and E.Natalizio. 2016. UAV-assisted disaster management: Applications and open issues. Proceedings of the 2016 International Conference on Computing, Networking and Communications (ICNC 2016), Kauai, HI, USA, 15-18 February 2016; IEEE: Piscataway, NJ, USA; 1-5.

European Council. 2017. Victims of Mount Agung Eruptions in Bali Receive EU Support. European Council. Last access on September 2020. https://ec.europa.eu/echo/news/victims-mount-agung-eruptions-bali$\underline{\text { receive-eu-support en }}$

Fang, S., X.Lida, Z. Yunqiang, Y. Liu, Z. Liu, H. Pei, J. Yan and Huifang Zhang. 2015 An integrated Information System For Snowmelt Flood Early-Warning Based on Internet of Things. Frontiers, 17 (2), 321-335.

France 24. 2017. Bali Closes Airport As Up To 100,000 Set To Evacuate. France 24. Last access on September 2020. https://www.france24.com/en/20171126-bali-volcano-eruption-disrupts-international-flights-mountagung

Fresh News Asia. 2017. Indonesia Declares Bali Returns to Normal, Airport Closure Unlikely. Fresh News Asia. Last access on September 2020. http://m.en.freshnewsasia.com/index.php/en/6432-indonesia-declares-balireturns-to-normal-airport-closure-unlikely.html

Fox News. 2017. Bali Volcano's Alert Status Lowered after Decreased Activity. Fox Media Group. Last access on November 2020. https://wtop.com/asia/2017/10/bali-volcanos-alert-status-lowered-after-decreasedactivity/ 
Gaudru, H. 2014. Volcano Tourism: The Effect of Eruptions and Disasters. In: Erfurt-Cooper P. (eds) Volcanic Tourist Destinations. Geoheritage, Geoparks and Geotourism (Conservation and Management Series). Springer, Berlin, Heidelberg. doi:10.1007/978-3-642-16191-9_26

Global Volcanism Program, 2018. Agung (264020) in Volcanoes of the World, v. 4.7.3. Venzke, E (ed.). Smithsonian Institution. Last access on November 2020, https: //volcano.si.edu/volcano. cfm? vn $=264020$

Grolinger, K., M. A. Capretz, E. Mezghani and E. Exposito. 2013. Knowledge as a Service Framework For Disaster Data Management. IEEE 22nd International Workshop on Enabling Technologies: Infrastructure for Collaborative Enterprises (WETICE), 2013, 313-318.

Humanitarian News. 2017. Indonesia: Half of Volcano Evacuees on Bali Are Asked to Go Home. Humanitarian News. Last access on November 2020. http://humanitariannews.org/20171001/indonesia-half-volcanoevacuees-bali-are-asked-go-home

Hopp, F. R., Schaffer, J., Fisher, J. T., \& Weber, R. 2019. iCoRe: The GDELT interface for the advancement of communication research. Computational Communication Research, 1(1), 13-44. doi:10.31235/osf.io/ smjwb.

Kamali, C. \& Augasta, M.G. 2017. Geo-Spatial Big Data Analysis: An Overview. International Journal of Trend in Research and Development (IJTRD), ISSN: 2394-9333.

Keertipati, S., M. K. Purvis and B. T. R. Savarimuthu. 2014. Multi-level Analysis of Peace and Conflict Data in GDELT. doi: 10.1145/2689746.2689750.

Kwak, H. \& An, J. 2014. Understanding News Geography and Major Determinants of Global News Coverage of Disasters. Computation+Jounalism Symposium, New York USA, 1-7.

Li, S., Dragicevic, S., Anton, F., Sester, M., Winter, S., Coltekin, A., ... Cheng, T. 2016. Geospatial Big Data Handling Theory and Methods: A Review and Research Challenges. I S P R S Journal of Photogrammetry and Remote Sensing, 115, 119-133. doi: 10.1016/j.isprsjprs.2015.10.012

Leetaru, K. and P. Schrodt. 2013. GDELT: Global Data on Events, Language, and Tone, 1979-2012. International Studies Association Annual Conference. San Diego, CA.

Mail Online. 2017. Bali Volcano Evacuees Outside Danger Zone Told To Go Home. Associated Newspapers Ltd. Part of the Daily Mail, The Mail on Sunday \& Metro Media Group. Last access on November 2020. https://www.dailymail.co.uk/wires/afp/article-4935564/Bali-volcano-evacuees-outside-danger-zone-toldhome.html

Marboen, A.P (ed). 2017. Volcanic Activity Of Mount Agung In Bali Increasing. Antara News. Last access on November 2020. https://en.antaranews.com/news/112675/volcanic-activity-of-mount-agung-in-baliincreasing.

Mudana, I.G., Sutama, Ketut \& Widhari, C.I.S. 2018. Local Community Entrepreneurship in Mount Agung Trekking. Journal of Physics: Conference Series, 953(1), 1-9. doi:10.1088/1742-6596/953/1/012107.

Nurhayati, D. 2017. Bali is world's top destination for 2017, says Tripadvisor. SPH Digital News/ Asiaone Group. Last access on November 2020, http://www.asiaone.com/travel/bali-worlds-top-destination-2017says-tripadvisor

Oman Daily Observer. 2017. Some Bali Flights Resume After Mount Agung Volcano Interrupts Travel. Oman Establishment for Press, Publication and Advertising (OEPPA). Last access on September 2020. http://www.omanobserver.om/bali-volcano-appears-calm/

Owuor, I., Hochmair, H. \& Cvetojevic, S. 2020. Tracking Hurricane Dorian in GDELT and Twitter. AGILE: GIScience Series, 1, 2020, full paper Proceedings of the 23rd AGILE Conference on Geographic Information Science, 1-18. doi:10.5194/agile-giss-1-19-2020.

Paris, N. 2017. Bali Named Greatest Destination on Earth by TripAdvisor. Fairfax Media. Last access on November 2020, http://www.traveller.com.au/bali-named-greatest-destination-on-earth-by-tripadvisorgvd0eo.

Parimartha, I.G., Gde Putra, I.B., Ririen, L. P. K. \& AAGN Ari Dwipayana (ed). 2016. Crescent On The Island Of Gods, Traces Of Islamic Village In Kusamba-Bali. Al-Albab. 5. 265. doi:10.24260/alalbab.v5i2.746.

Phys.org. 2017. Indonesia Raises Alert Level for Bali Volcano. Associated Newspapers Ltd. Last access on November 2020. https://phys.org/news/2017-09-indonesia-bali-volcano.html

Pratiwi, D.P.E., Sulatra, I.K. \& Candra, K.D.P. 2019. Bali Tourism Advertisements: A Linguistic Analysis. International Journal of Linguistics, Literature and Culture, 5(1), 43-53. doi;10.21744/ijllc.v5n1.582

Rahman, M. S. L., Di and M. Esraz-Ul-Zannat .2017. The Role of Big Data in Disaster Management. Proceedings, International Conference on Disaster Risk Mitigation, Dhaka, Bangladesh.

Rahmawati, P.I., Trianasari \& Martin, A.A.N.Y. 2019. The Economic Impact of Mount Agung Eruption on Bali Tourism. Advances in Economics, Business and Management Research, 69, $3^{\text {rd }}$ International Conference on 
Tourism, Economics, Accounting, Management, and Social Science, 98-107. doi: 10.2991/teams18.2019.18.

Richardson, D.B., Volkow, N.D., Kwan, M.-P., Kaplan, R.M., Goodchild, M.F., Croyle, R T., 2013. Spatial Turn in Health Research. Science 339, 1390.

Relief Web. 2017. Half of Volcano Evacuees on Bali Are Asked to Go Home. ReliefWeb. Last access on November 2017. https://reliefweb.int/report/indonesia/half-volcano-evacuees-bali-are-asked-go-home

Republika Online. 2017. Mt Agung Erupts, Releases Volcanic Ash And Smoke. Republika.Co.Id. Last access on November 2020. https://www.republika.co.id/berita/en/national-politics/17/11/21/ozrwc4414-mt-agungerupts-releases-volcanic-ash-and-smoke.

Robinson, W.S., 2009. Ecological Correlations and the Behavior of Individuals. International Journal of Epidemiology. 38, 337-341.

Rosselló J., Becken S. \& Santana-Gallego M. 2020. The effects of natural disasters on international tourism: A global analysis. Tourism Management, 79, 1-11. doi: 10.1016/j.tourman.2020.104080.

Shu, H. 2016. Big Data Analytics: Six Techniques. Geo-spatial Information Science, 19(2), 119-128, doi: 10.1080/10095020.2016.1182307.

Su, Y., Lan, Z., Lin, Y., Comfort, L.K. \& Joshi, J. 2016. Tracking Disaster Response and Relief Following the 2015 Nepal Earthquake. IEEE 2nd International Conference on Collaboration and Internet Computing (CIC), Pittsburgh, PA, 495-499. doi:10.1109/CIC.2016.075.

Song, X., Q. Zhang, Y. Sekimoto, R. Shibasaki, N. Jing Yuan and Xing Xie. 2015. A Simulator of Human Emergency Mobility Following Disasters: Knowledge Transfer from Big Disaster Data. AAAI, 2015, 730736.

Tallon, M. 2013. Reflections from Bali: The Island of God. Oath Inc. Last access on November 2020. Retrieve from https://www.huffingtonpost.com/monique-svazlian-cpcc-acc/bali-travel_b_4019409.html.

The Daily Mail. 2017. Indonesia Raises Alert Level for Bali Volcano. Associated Newspapers Ltd. Last access on November 2020. https://www.dailymail.co.uk/wires/ap/article-4884234/Indonesia-raises-alert-levelBali-volcano.html

The Denver Post. 2017. Bali Authorities Urge Many Who Fled Volcano to Return Home. Digital First Media. Last access on November 2020. https://www.denverpost.com/2017/09/30/mount-agung-volcano-balipeople-fleeing/

The GDELT Project. 2019. A global database of society. Last access on November 2020, https://www.gdeltproject.org

The Hindu. 2017. Indonesia Raises Alert Level for Bali Volcano. The Hindu. Last access on November 2020. https://www.thehindu.com/news/international/indonesia-raises-alert-level-for-balivolcano/article19684655.ece

The Indian Express. 2017. Some Bali Flights Resume After Mount Agung Volcano Interrupts Travel. The Indian Express. Last access on November 2020. https://indianexpress.com/article/world/some-bali-flights-resumeafter-mount-agung-volcano-interrupts-travel-4954922/

The Star Online. 2017. Dozens of Flights Cancelled As Bali Volcano Continues To Spew Smoke. Star Media Group Berhad (ROC 10894D). Last access on November 2020. https://www.thestar.com.my/news/regional/2017/11/26/dozens-of-flights-cancelled-as-bali-volcanocontinues-to-spew-smoke/

The Washington Times. 2017. Indonesia Raises Alert Level for Bali Volcano. The Washington Times, LLC. Last access on November 2020. https://www.washingtontimes.com/news/2017/sep/14/indonesia-raises-alertlevel-for-bali-volcano/

Wesnawa, I.G.A. 2017. Sustainable Tourism Development Potential in the Improvement of Economic and Social Life Community Corridor in Bali. International Research Journal of Management, IT \& Social Sciences, 4(3), 1-12. https://sloap.org/journals/index.php/irjmis/article/view/391

Whiteside, D. 2017. Volcano On Indonesia's Bali Island At Highest Alert Level, Thousands Evacuated. Reuters. Last access on November 2020. https://uk.reuters.com/article/uk-usa-nuclear-russia/u-s-would-destroybanned-russian-warheads-if-necessary-nato-envoy-idUKKCN1MC1J2

World Buletin. 2017. Flights Resume as Bali's Volcano-Hit Airport. World Buletin. Last access on November 2020. https://www.worldbulletin.net/asia-pacific/flights-resume-as-balis-volcano-hit-airport-h196420.html

Xinhua News. 2017. Indonesia's Mount Agung Volcano Erupts. Xinhuanet. Last access on November 2020. http://www.xinhuanet.com//english/2017-11/21/c 136769370.html 